\title{
ビギナーズセミナー 2
}

\section{BS2}

\section{2 型自然リンパ球の役割}

理化学研究所 統合生命医科学研究センター 自然免疫システム研究チーム

横浜市立大学医学研究科 免疫生物学研究室

茂呂和世

抗原特異的な受容体を発現し獲得免疫で働く $\mathrm{T}$ 細胞, B 細胞に対し，抗原受容体を持たず自然免疫で働く リンパ球を Innate lymphoid cells（ILC）と呼ぶことが定着してきた。細胞傷害性をもつリンパ球として古くか ら知られる NK 細胞に加えて近年同定された NK 様細胞 ILC1 はグループ 1 ILC に分類され, 当研究室で 2010 年に報告した Natural Helper（NH）細胞や Nuocyte, Ih2 細胞はグループ 2 ILC（ILC2s），リンパ節形成に重要な 役割を持つことが知られているLTi 細胞と粘膜バリアに働くことが明らかになりつつある ILC3 はグループ 3 ILC に分類されるようになった，獲得免疫系のリンパ球が抗原を認識し活性化するのに対し，すべての自然免 疫系リンパ球の活性化はサイトカインによって誘導される，グループ 1 ILC は IL-12 や IL-18 によって, グルー プ 2 ILC は IL-25 や IL-33 によって，グループ 3 ILC は IL-1 や IL-23によって活性化する，サイトカインによ る自然リンパ球の活性化は, 活性化までに時間を要する獲得免疫系のリンパ球が立ち上がるまでの生体防御に 重要と考えられる.

グループ 2ILC は総じて ILC2 と呼ばれており, 寄生虫感染排除における重要性が報告される一方で様々な アレルギー性疾患に打ける負の働きも明らかになってきた。また, 炎症後の組織修復や, 代謝疾患への関与も 示唆されている。本講演では，ILC2の疾患における動態について最新の知見を交えながらわかりやすく概説 する. 